\title{
Alliance Management as Source of a Successful Strategy
}

\author{
Margherita Russo \\ Department of Economics, Management and Statistics, \\ University of Milano-Bicocca, Italy
}

doi: 10.19044/esj.2017.v13n7p110 URL:http://dx.doi.org/10.19044/esj.2017.v13n7p110

\begin{abstract}
In today's global environment, strategic alliances represent an important source of growth and competitive advantage; they allow firms to access new and critical resources and capabilities, to improve competitive position and rapidly to enter a new market In spite of the strategic importance of the alliances, they still exhibit a high failure rate; previous researches show that the half of the alliance formed end up as failure. The low success rate testifies firms' difficulties in managing their alliance relationships and in ensuring enough success from them. In global markets, firms exhibit heterogeneity in terms of the overall alliance success; some firms achieve success from their alliance and others fail. Although most companies have realized the importance of strategic alliances, only few of them have developed the needed capabilities to manage them with success. In recent years, empirical studies found that firms with greater alliance success are those ones with superior management capabilities, termed in literature as "alliance capabilities". This study is based on the assumption that the heterogeneity in alliance success rate is due to heterogeneity in firms’ level of management capabilities. Eli Lilly \& Company’s success in strategic alliances represents a clear example of company that understood the importance of developing an institutionalized approach of "alliance management" that improves the likelihood of alliance success.
\end{abstract}

Keywords: Strategic alliances, Successful strategy, alliance management capabilities

\section{Introduction}

The increasing turbulence and instability of global markets, characterized by hyper-competition, makes difficult for companies to preserve their own competitive position; they cannot compete in the marketplace just with their own resources' endorsement, that's why they are 
increasingly dependent on external partners, which allow firms to fill the gap of needed resources, knowledge and skills. Competition is no more between individual firms but between alliance networks (Brondoni, 2010). Firms set cooperative strategies with a wide range of solutions of equity and nonequity alliances, with the aim to create value through several sources: scale economies, effective risk management, cost efficient market entries and, especially, learning from partners (Arrigo, 2012).

Strategic alliances are forms of collaboration, which enable market entry, increase the resource base of the partners through sharing of core competencies (Varma et al., 2015) and allow firms to gain and maintain competitive advantage (Cobeña et al., 2017). Although they become very popular as cornerstones for competitive strategies of many firms (Ziggers \& Tjemkes, 2010), their success rate remains rather low. Previous researches show that the half of the alliance formed end up as failure (Lunnan \& Haugland, 2008; Kale \& Singh, 2009; Madhok et al., 2015; Linwei et al., 2017). In many cases, the causes of alliance failure are due to the nature of alliances, which are characterized by the simultaneous presence of cooperation and competition (Ireland et al., 2002). In fact alliance literature indicates that partnerships are associated not only with cooperation but also with competition (Madhok et al., 2015). Cooperation is related to the common interest, instead competition is due to partners' benefits. Park \& Ungson (2001), on this assumption, identify two main causes of alliance failure such as:

- $\quad$ Inter-firm competition: risk of partner's opportunistic behavior.

- $\quad$ Managerial complexity: coordination problems due to potential lack of cultural, strategic and structural fit between partners.

Alliance failure could represent value destruction for firms, which have invested many financial resources. Bamford et al. (2004) observe that around $30 \%-70 \%$ of alliances fail without achieving shared goals or operational benefits. The high alliance failure rate highlights that firms encounter some difficulties to manage their alliance and lead them towards success; in fact, not all the companies have experience and capabilities necessary to obtain sufficient success from their collaborative relationships. In global markets, firms exhibit heterogeneity in terms of overall alliance success (Kale \& Singh, 2009); as a matter of fact, empirical studies found that companies with greater alliance success are those ones with superior capabilities, termed in literature as "alliance capabilities" (Ireland et al., 2002; Kale \& Singh, 2009; Saebi, 2011; Duysters et al., 2011; Wang \& Rajagopalan, 2015). Alliance management is crucial for firms to gain competitive advantage and create value, that's why is considered a source of alliance success. The concept of alliance capability is useful to justify the heterogeneity in alliance success rate among companies. 


\section{Literature review and hypothesis}

\section{Alliance capability: an overview}

Alliance capability view gained in importance in 1990's and it is an extension of the Dynamic capability theory, which is useful to detect and elucidate conditions that made alliance successful (Saebi, 2011). Dynamic capability view (Teece et al., 1997) explains how companies can achieve sustainable competitive advantage, pointing out that resources' endowment is no more enough to justify heterogeneous performance among firms. Markets are not static and under unpredictable conditions, the theory emphasizes the reconfiguration of basic resources. Dynamic capability concept refers to firms' abilities to promote changes with the integration, building and reconfiguration of basic resources in matching changing environments. In situation of rapid environment change, companies have to develop capabilities (high-order resources), improving the productivity of basic resources. Dynamic capabilities are heterogeneously distributed among companies and that's why they are a source of competitive advantage. Many previous studies held that alliance capabilities are a kind of dynamic capability (Heimeriks \& Schreiner, 2010), as matter of fact they are highorder of resources that influence the lower-order of alliance resources such as several alliance relationships' attributes (Schilke \& Goerzen, 2010). They promote alliance success because allow partner to adjust alliance attributes (such as knowledge sharing between partners and collective goals) to changes in the environment (Neisten \& Jolink, 2015). Alliance capabilities, just like Dynamic capabilities, are heterogeneously distributed across firms and for such a reason, they are able to justify heterogeneous alliance success rate among companies. As stated by Saebi (2011), Alliance capability view capability promotes a shift in research focus from relational or structural factors, peculiar to the individual alliance relationship, towards managerial capabilities specific of a single firm. This stream of thought is specifically focused on organizational capabilities rather than on the traditional dyadic and relational characteristic for explain alliance success (Ziggers \& Tjemkes, 2010); companies have to focus not only on the relationship between partners, but equally on capabilities requested for managing it (Duysters et al., 2011). According to such an assumption, firms with high alliance success rate are those ones with a higher degree of alliance capabilities. Thus, differences in alliance success among firms, are due to different level of capabilities in managing alliances. As for alliance capability meaning, Saebi (2011) identified two main schools of thought. Both of them point out two different and important aspects of the concept. The first one describes alliance capability as a learning capability of alliance management (Kale et al., 2001; Draulans et al., 2003; Heimeriks \& Duysters, 2007); it stresses the importance of learning process as a key determinant of alliance capabilities. 
According to such point of view, prior experience plays a critical role in alliance capabilities development. Firms, engaging in numerous alliances, gain experience about alliance management and transform it into accessible lessons that are shared and disseminated throughout organization (Gulati, 1995; Kale et al., 2002; Saebi, 2011). The second stream of research (Lambe et al., 2002; Schreiner et al., 2009) describes alliance capabilities abilities in managing alliance's tasks during the phases of its lifecycle. Saebi (2011), with the aim to provide a clear vision of alliance capabilities' concept, integrates the two types of definition into one as follow: "Alliance capabilities are an institutionalized approach to learning about alliance management in order to support the organization in the formation, operation and evaluation of its alliance”.

\section{Alliance capabilities development}

Alliance capabilities are superior abilities to capture, share and store knowledge on alliance management, gained from prior experience, and which it's been used in ongoing and future alliances (Kale \& Singh, 2009). According to such assumptions, prior alliance experience plays a critical role in alliance capabilities development. Gulati (1995) defines alliance experience as firms' expertise on alliance management gained from prior alliances; firms, engaging themselves in a great number of alliances, learn about crucial aspects of alliance management, which are translated in alliance know-how (Kale et al., 2002). In fact, strategic alliances are popular vehicle for organization learning and knowledge sharing (Jiang et al., 2016). Firms, accumulating experience, learn how to manage successfully their strategic alliances; such assumption highlights firms' abilities to create value from their previous alliance experience. Firms, which frequently engage in strategic alliances, are more likely to benefit of superior alliance know-how that in turn allows the development of high order of alliance management capabilities (Sluyts et al., 2011); different levels of alliance experience justify different levels of alliance management capabilities, owned by firms. It is expected that, firms with more alliance experience develop superior capabilities in managing strategic alliance than those with lesser. However, previous researches state that alliance experience provides only a crude approximation of the mechanisms that lie at the foundation of alliance capabilities development; it is an important but not sufficient condition because lessons learned from previous experience have to be articulated, codified, shared and internalized in alliance management know-how. In order to leverage previous alliance experience, firms have to invest in learning mechanisms identified by Kale \& Singh (2009) as follow: alliance know-how articulation, codification, sharing and internalization. In order to foster the learning process, alliance literature (Kale \& Singh, 2009; Sluyts et 
al., 2010; Duyster et al., 2011; Saebi, 2011; Neisten \& Jolink, 2015) stresses the implementation of structures, process and tools such as Corporate alliance office, alliance managers, formal and informal de-briefing, rotation of alliance managers, formal and informal knowledge exchange logbook on alliance events and internal reports on alliance management, management guidelines, templates, databases, checklists and manuals, internal and external training programs. In order to achieve successful alliances, firms needed to develop an institutionalized approach to learning that allows them to transform prior alliance experience in accessible lessons and best practices, which are shared and disseminated throughout the organization (Draulans et al., 2003) and support companies in decision-making and management process for future alliances. Firms' major effort, in alliance capabilities development process, is represented by the creation of a separate structure or entity, which supports the learning process and firm's overall alliance activity, referred to as "dedicated alliance function"; it is represented by an alliance department or office (Kale et al., 2002; Borker et al., 2004). Alliance function acts as a central coordination mechanism able to promote alliance capabilities development and with the aim to increase the overall alliance success likelihood. Empirical studies, led by Kale et al. (2002), demonstrate that firms are more likely to achieve success from their strategic alliances if they invest in creating a dedicated alliance function, which helps to accumulate, integrate and codify alliance know-how in manuals and guidelines for supporting managers in handling alliance during the phases of its lifecycle. Alliance function acts as a focal point for learning and leveraging explicit and tacit alliance know-how form prior experience; in matter of fact, training programs and internal meeting allow managers to share their tacit knowledge such as experience gained in carrying out several tasks of alliance management. Thus, alliance functions represents a depository of alliance know-how, without it, the knowledge owned by individual manager could be lost if they left the firms. Indeed, a dedicated alliance function, allows the coordination of internal resource across different alliance divisions and acts as a facilitator to resolve potential conflicts among partners (Kale et al., 2002). Investing in a dedicated alliance leads to the implementation of a stronger learning process (Kale \& Sing, 2009). In the light of such arguments, it follows that some firms are more capable of attaining success from their strategic alliance due to their previous experience and alliance knowledge acquired through the development of an institutionalized approach to learning about alliance management. On the base of these theoretical assumption, I can formulate the following hypothesis:

H1: Firms, which have developed an institutionalized approach to learning about alliance management with standardized procedures, tools 
and a dedicated alliance function, are supposed to be more successful in their strategic alliance.

H2: The source of alliance success lies in alliance management process.

\section{Methodology}

In scientific researches there are three basic approaches: qualitative, quantitative and a combination of them. Quantitative research is adopted when assessing objective theories by examining the relationship among variables; instead qualitative one is employed while exploring and gaining understanding of the meaning that both individuals and organizations give to a societal or organizational problem (Creswell, 2009). The main differences between the two methods is that whereas quantitative strategies revolve entirely around numbers, qualitative one involves words. Bryman (2008) highlights that the qualitative approach is more appropriate when the purpose involves exploration and understanding of the research problem. Such aspect of qualitative research makes it more suitable for the present research problem, compared to quantitative research. Therefore, for my study a qualitative approach was adopted. In terms of qualitative research, the case study method was chosen as most appropriate for addressing the research purposes of this research. In fact, in choosing between several strategies, an important aspect to consider is represented by the research question of the study (Yin, 2009). Eriksson \& Kovalainen (2008) state that case studies should be adopted if the research questions are related to complex managerial and/or organizational business concerns; in such cases, the subjects need to be examined from more than one perspective and thus can be difficult to investigate while using a quantitative research approach. "How" and "why" questions are more efficiently approached using case study method. In order to formulate the questions, a literature review is conducted for identifying what research has been previously conducted and leads to refined, insightful questions about the problem. My research aim to illustrate the subject of alliance management capabilities and verify whether existing theory on the subject is representative of the point of view of concerned firm. Yin (2009) states that a case study of qualitative nature is desired when research question "deals with operational links needing to be traced over time”. The author defines case study as an empirical inquiry that investigates a contemporary phenomenon within its real-life context, when the boundaries between phenomenon and context are not clearly evident and in which multiple sources of evidence are used. Case study relies on multiple sources as well as surveys, interviews, documentation review, observation, and even the collection of physical artifacts (Yin, 2009). According to Creswell (2009) case study method allows the researchers the opportunity to 
collect detailed information adopting many kinds of procedures over a specific time period. In my research, I choose to adopt such method in order to reflect in the case study the theoretical hypothesis previously defined.

\section{Eli Lilly \& Co case study}

The purpose of the present article is to examine how the alliance management process contributes to alliances success. To this aim, it has been chosen "Eli Lilly \& Co" case study. Eli Lilly \& Company is an American global pharmaceutical company founded in 1876 and headquartered in Indianapolis (Indiana, Us). The firms is considered a "premium partner" in the pharmaceutical industry.

Such case has been selected for several reasons:

- In Eli Lilly \& Co, it has been possible to observe a clear manifestation and a deep insight into alliance management phenomenon.

- $\quad$ Eli Lilly \& Co. looks at strategic alliances as an important cornerstone of its business strategy; it realized that in today global market, innovative partnerships are the key to achieve success. The company has currently over one hundred partnerships around the world devoted to discovery, development, and marketing. The partnerships allow the firm to usher new ideas from discovery to development and commercialization such as the worldwide licensing and collaboration agreement with Zymeworks, the co- development and co- commercialization agreement with AstraZeneca and the exclusive license and collaboration agreement with Hanmi Pharmaceutical (Eli Lilly \& Co Global website). Jan Lundberg, the executive vice president for science and technology and president of Lilly Research Laboratories, states that: "We continue to build a sustainable R\&D program by integrating our internal efforts with broad access to external innovation”.

- $\quad$ Eli Lilly \& Co, in order to establish an alliance process efficient for managing every corporate alliance relationship, created the "Office of Alliance Management” in 1999. The company was the first in their industry to establish an office devoted to alliance management.

The information used for case study come from an extensive review of articles of international academic journals and articles sponsored by the company and written by its professionals involved in the alliance management process. Others secondary information from its official global website are also used to improve the research validity. The company through its web site offers an interesting insights and contents regarding the alliance management process.

\section{Findings}

From the case study analysis emerged that Eli Lilly \& Co. developed a systematic approach to learning about alliance management in order to 
support the company in the management of its strategic alliances. Eli Lilly's evidence confirms the theoretical hypothesis of this study. In fact, Eli Lilly's success in strategic alliances lies in its own effort in creating a dedicated alliance structure (Ely Lilly's Office of Alliance Management) and developing several tools and procedures for supporting the alliance management and fostering the alliance know-how sharing throughout the organization in the form of usable lessons and best practices. The Office of Alliance Management is a systematic structure responsible for developing and improving tools and learning processes to support the alliance management. Such tools cover each phase of alliance lifecycle, define the dimensions of a good partnering, allow to translate lesson learned in alliance management know-how, share it throughout the organization and assess each alliance's health.

It has been identified three primary tools:

- $\quad$ “3D Fit” (Three- dimensional fit) is a tool developed by the company to assess, during due diligence and contracting, partner compatibility across three dimensions: cultural fit (compatibility of the management style and culture), operational fit (how the operational aspects of the business model complement each other) and strategic fit (the alignment of partners' objectives). The aim of this tool is to go beyond the traditional assessment of operational compatibility and ensure that strategic and cultural partners' compatibility are being addressed and tracked over the time (Twait \& Thompson, 2012).

- $\quad$ Voice of the Alliance” (VOA) is a tool developed for the annual alliance health assessment and with the aim to evaluate the current state of partnership and identify issues requiring attention (Thompson \& Twait, 2012). The Voice of the alliance is a web- based survey, administered by Eli Lilly and its partner, including questions across 14 dimensions crucial to a healthy alliance such as communication, trust, commitment etc. (Futrell et al, 2001); the results show how each partner views each dimension, the areas in which the alliance is doing well and those that need improvement or immediate attention (Gueth, 2001). According to Futrell et al. (2001) the tool allows Eli Lilly and its partners to have a picture of the health and effectiveness of the alliance in a specific moment of its life.

"Partners" is an online database, which is accessed by anyone involved in an alliance and contains lessons learned, milestone and budget reporting, process and tools (Sims, 2001). The database promotes training and allows to develop needed skills in using alliances' tools and process. Eli Lily \& Co develops such tools with the aim to systematically capture, codify and share what it has been learned from each alliance, has created a specific tool referred to as. 
The Office of Alliance Management is part of a larger framework Eli Lilly's alliance management process; in fact each alliance has its own threeperson management lead team responsible for the overall alliance success (Sims et al., 2001): alliance champion, alliance leader and alliance manager. The alliance champion, usually played by a senior executive, which is responsible for the entire alliance process and mainly for promoting communication between partners, with the aim to break down potential barriers that can jeopardize alliance relationship. The alliance leader, usually played by a project manager with expertise in the specific operational area, is responsible for alliance day to day operation and for the overall alliance project implementation. The alliance manager supports the alliance leader and serves as an advocate for the alliance. Stach (2006) states that the main manager's task is to serve as "ombudsman", working on behalf of the overall alliance success. Alliance managers develop close relationships with partners and build alliance capabilities, defining and applying key lessons from their previous alliance experience. They capture, codify and share alliance knowhow throughout organization for supporting the management of future alliances (Sims et al., 2001). Experienced alliance managers act as trainers because, as asserted by Stach (2006), nobody knows more about tools and techniques of successful alliance than them. Alliance managers come from different backgrounds, they are recruited from several disciplines at Eli Lilly such as corporate affairs, finance, marketing and not only from R\&D (Sims et al., 2001); in fact as stated by Hawkins et al. (2014) in their paper about the importance of developing great alliance managers, a successful alliance manager possesses a combination of interpersonal, professional and alliance specific competencies. Their business background and specific alliance management competencies, represent the essential requisites to identify a professional alliance managers capable to maximize value and minimize risk. The required skills, knowledge and capabilities to be successful in alliance management role, have been structured at Ely Lilly into a model referred to as Alliance Management Competency Model (Hawkins et al., 2014). The Model classifies the alliance managers' competencies in two categories: operational and foundational competencies. The foundational ones show how an alliance manager can best carry out its role; Hawkins et al. (2014) state that, because of the wide range of personalities and experience involved, they are difficult to structure. Foundational competencies go beyond identifying a specific task and refer to alliance manager's approach and qualities in carrying out it such as demonstrating vision, judgment and influence to evaluate a human, business and legal risk. Thompson \& Twait (2011) believe that alliance success, in today's challenging environment, lies on the ability to proactively mitigate and manage business risk, human risk and legal uncertainties; managing risk should and must be alliance managers' 
main goal. Therefore, foundational competencies allow alliance managers to identify, prevent and mitigate alliance risks. The Operational competencies, instead, identify specific tasks performed by alliance managers, during alliance management process. They include several alliance managers' tasks: developing potential alliances; forming alliance; manage ongoing alliance; building partner knowledge; promoting alliance change (Hawkins et al., 2014).

Considering the key tasks in alliance management process, the alliance manager represents the Office of Alliance Management; they are at the heart of any business alliance (Hawkins et al., 2014).

Finally, Eli Lily \& CO has developed an institutionalized approach to alliance management, which works through a relatively predictable lifecycle common to every corporate alliance relationship (Stach, 2006).

Eli Lilly’s approach for a successful alliance management is based on some essential assumptions:

The importance of creating a dedicated organizational structure and tools (Ely Lilly's Office of Alliance Management), which captures, codifies and shares alliance management knowledge; it is as a feedback loop in which experience and lessons learned from one alliance influence the management of the future ones.

- $\quad$ The importance of creating replicable processes that can be applied from alliance to alliance. Development and application of alliance best practices allow company to replicate the success.

\section{Conclusion}

The case study provides a more practical insight into the alliance management process. Theoretical assumptions discussed in the literature review are reflected on a real alliance management process. In fact, Eli Lilly's evidence confirms the premise of Alliance capability view, which states that alliance success lies not only on the relationship between partners, but equally on firms' capabilities to manage strategic alliances. The success of the company in alliance strategies is the demonstration that firms with high alliance success rate are those ones with a higher degree of alliance capabilities. Eli Lilly \& Co ‘s alliance success lies exactly in firm’s alliance management process that is crucial to gaining competitive advantage and creating value from strategic alliance. From a theoretical point of view, the study contributes to provide a clear and unified overview about the alliance management capabilities development process. From a managerial point of view, it highlights the importance of developing a dedicated organizational structure, tools or procedures that capture, codify and share alliance knowledge in the form of best practices and supports the management of future alliances. Firms, in order to achieve success from their strategic 
alliance, have to develop an institutionalized approach to learning from prior alliance experience. However, this study have some limitations. First, the case study is based only on secondary information achieved from multiple sources, including company publications, annual reports, web pages and scientific publications. Further researches should test the validity of my study through a more qualitative (as well as explorative interviewees or structured questionnaire) or quantitative research. Moreover, even if a single case study provides a concrete insight of the invested phenomenon, it cannot be representative at all. Further researches should be conducted through a multiple-case design.

\section{References:}

1. Arrigo, E. (2012). Alliances, Open Innovation and Outside-in Management. Symphonya. Emerging Issues in Management (symphonya.unimib.it), 2, 53-65.

2. Bamford, J., Ernst, D., \& Fubini, D. G. (2004). Launching a worldclass joint venture. Harvard business review, 82(2), 90-100.

3. Bryman, A., (2008). Social Research Methods, (third edition), Oxford University Press, Oxford.

4. Brondoni, S. M. (2010). Intangibles, Global Networks \& Corporate Social Responsibility. Symphonya. Emerging Issues in Management (symphonya.unimib.it), 2, 6-24.

5. Cobeña, M., Gallego, Á., \& Casanueva, C. (2017). Heterogeneity, diversity and complementarity in alliance portfolios. European Management Journal.

6. Creswell, J., W., (2009). Research Design: Qualitative, Quantitative, and Mixed Methods Approaches. 3rd Edition. Los Angeles: Sage Publications, Inc.

7. Draulans, J., DeMan, A. P., \& Volberda, H. W. (2003). Building alliance capability: Management techniques for superior alliance performance. Long Range Planning 36(2) 151-166.

8. Duysters, G., Saebi, T., \& De Man, A. P. (2011). Shaping the alliance management agenda: a capability approach. Journal on Chain and Network Science, 11(3), 191-196.

9. Eli Lilly \& CO. (2017). Homepage. Who we are. Retrieved by February 1, 2017, from https://www.lilly.com/who-we-are.

10. Eli Lilly \& CO. (2017). Partners. Scientific Partnering. Retrieved by February 1, 2017, from https://www.lilly.com/partners.

11. Eriksson, P., Kovalainen, A. (2008). Qualitative methods in business research. Sage, London.

12. Futrell, D., Slugay, M., \& Stephens, C. H. (2001). Becoming a premier partner: Measuring, managing and changing partnering 
capabilities at Eli Lilly and Company. Journal of Commercial Biotechnology, 8(1), 5-13.

13. Gueth, A. (2001). Entering into an alliance with big pharma. Pharmaceutical Technology, 25(10), 132-138.

14. Gulati, R. (1995). Does familiarity breed trust? The implications of repeated ties for contractual choice in alliances. Academy of management journal, 38(1), 85-112.

15. Hawikins, R. E., May, J. L. C., Thompson, D.S, \& Twait, S. E. (2014). Role Modeling: a structured approach to developing great alliance managers. Strategic Alliance Magazine, Quarter 1, 39-43.

16. Heimeriks, K. H., \& Duysters, G. (2007). Alliance management capability as a mediator between experience and alliance performance: an empirical investigation into the alliance management capability development process. Journal of Management Studies, 44(1), 25-49.

17. Heimeriks, K. H., \& Schreiner, M. (2010). Relational quality, alliance capability, and alliance performance: An integrated framework. In Enhancing Competences for Competitive Advantage. Emerald Group Publishing Limited, 145-171.

18. Ireland, R. D., Hitt, M. A., \& Vaidyanath, D. (2002). Alliance management as a source of competitive advantage. Journal of management, 28(3), 413-446.

19. Jiang, X., Bao, Y., Xie, Y., \& Gao, S. (2016). Partner trustworthiness, knowledge flow in strategic alliances, and firm competitiveness: A contingency perspective. Journal of Business Research, 69(2), 804-814.

20. Kale, P., Dyer, J. H., \& Singh, H. (2002). Alliance capability, stock market response, and long-term alliance success: the role of the alliance function. Strategic Management Journal, 23(8), 747-767.

21. Kale, P., \& Singh, H. (2009). Managing strategic alliances: What do we know now, and where do we go from here. Academy of management perspectives, 23(3), 45-62.

22. Lambe, C. J., Spekman, R. E., \& Hunt, S. D. (2002). Alliance competence, resources, and alliance success: conceptualization, measurement, and initial test. Journal of the academy of Marketing Science, 30(2), 141-158.

23. Linwei, L., Feifei, J., Yunlong, P., \& Nengqian J. (2017). Entrepreneurial orientation and strategic alliance success: The contingency role of relational factors. Journal of Business Research, 72, 46-56. 
24. Lunnan, R., \& Haugland, S. A. (2008). Predicting and measuring alliance performance: A multidimensional analysis. Strategic Management Journal, 29(5), 545-556.

25. Madhok, A., Keyhani, M., \& Bossink, B. (2015). Understanding alliance: Adjustment costs and the economics of resource value. Strategic Organization, 13(2), 91-116.

26. Niesten, E., \& Jolink, A. (2015). The impact of alliance management capabilities on alliance attributes and performance: a literature review. International Journal of Management Reviews, 17(1), 69100.

27. Park, S. H., \& Ungson, G. R. (2001). Interfirm rivalry and managerial complexity: A conceptual framework of alliance failure. Organization science, 12(1), 37-53.

28. Saebi, T. (2011). Succesfully managing alliance portfolios: An alliance capability view. Doctoral dissertation: Maastricht University.

29. Schilke, O., \& Goerzen, A. (2010). Alliance management capability: an investigation of the construct and its measurement. Journal of Management, 36(5), 1192-1219.

30. Schreiner, M., Kale, P., \& Corsten, D. (2009). What really is alliance management capability and how does it impact alliance outcomes and success?. Strategic Management Journal, 30(13), 1395-1419.

31. Sims, N., Harrison, R., \& Gueth, A. (2001). Managing alliances at Lilly. IN VIVO-NEW YORK-, 19(6), 71-77.

32. Sluyts, K., Matthyssens, P., Martens, R., \& Streukens, S. (2011). Building capabilities to manage strategic alliances. Industrial Marketing Management, 40(6), 875-886.

33. Stach, G. (2006). Business alliances at Eli Lilly: A successful innovation strategy. Strategy \& Leadership, 34(5), 28-33.

34. Teece, D. J., Pisano, G., \& Shuen, A. (1997). Dynamic capabilities and strategic management. Strategic management journal, 18(7), 509-533.

35. Twait, S. E., \& Thompson, D.S. (2011). High risk to high reward: How to dig in, solve problems and create a valued Alliance Management Function. Strategic Alliance Magazine, Quarter 3, 3741.

36. Twait, S. E., \& Thompson, D.S. (2011). High risk to high reward: Using the skills and the tools of servant leadership to manage risk. Strategic Alliance Magazine, Quarter 4, 36-39.

37. Twait, S. E., \& Thompson, D.S. (2012). Governance by Design: How well- established principles and practices set the stage for alliance success. Strategic Alliance Magazine, Quarter 3, 25-29. 
38. Twait, S. E., \& Thompson, D.S. (2012). Go to go: How setting the right tone, goals and expectations gets a great alliance going. Strategic Alliance Magazine, Quarter 4, 1-5.

39. Varma, S., Awasthy, R., Narain, K., \& Nayyar, R. (2015) Cultural determinants of alliance management capability - an analysis of Japanese MNCs in India, Asia Pacific Business Review, 21(3), 424448

40. Wang, Y., \& Rajagopalan, N. (2015). Alliance capabilities: review and research agenda. Journal of Management, 41(1), 236-260.

41. Yin, R.K., (2009). Case Study Research: Design and Methods, Sage Publications, London.

42. Ziggers, G. W., \& Tjemkes, B. (2010). Dynamics in inter-firm collaboration: The impact of alliance capabilities on performance. International Journal on Food System Dynamics, 1(2), 151-166. 